\title{
T Cell-Epstein-Barr Virus-Associated Hemophagocytic Lymphohistiocytosis (HLH) Occurs in Non-Asians and Is Associated with a T Cell Activation State that Is Comparable to Primary HLH
}

\author{
Oded Shamriz ${ }^{1,2} \cdot$ Deepak Kumar ${ }^{1,2} \cdot$ Jenny Shim ${ }^{1,2} \cdot$ Michael Briones $^{1,2} \cdot$ Maa-Ohui Quarmyne ${ }^{1,3}$. \\ Satheesh Chonat ${ }^{1,2} \cdot$ Laura Lucas $^{4} \cdot$ Holly Edington $^{1,2} \cdot$ Michael H. White $^{1,2} \cdot$ Advay Mahajan $^{1,2} \cdot$ Sunita Park $^{5}$. \\ Shanmuganathan Chandrakasan ${ }^{1}$ (D)
}

Received: 31 March 2021 / Accepted: 20 May 2021 / Published online: 26 June 2021

(c) The Author(s), under exclusive licence to Springer Science+Business Media, LLC, part of Springer Nature 2021

\begin{abstract}
Purpose T cell-Epstein-Barr virus-associated hemophagocytic lymphohistiocytosis (T cell-EBV-HLH) is prevalent in East Asia and has poor prognosis. Understanding of this disease is limited, and literature regarding prevalence in North America is scarce. Herein, we summarize our experience.

Methods A retrospective analysis of T cell-EBV-HLH patients admitted to Children's Healthcare of Atlanta (GA, USA) from 2010 to 2020 was conducted. Additional immune studies were completed in a subset of patients.

Results We report 15 patients (10 months-19 years of age) diagnosed with T cell-EBV-HLH. Nine patients were Hispanic, and the majority did not have primary HLH (p-HLH) gene defects. Soluble interleukin-2 receptor levels in T cell-EBV-HLH were significantly higher than other forms of secondary-HLH but comparable to $\mathrm{p}-\mathrm{HLH}$, and it correlated with disease severity at presentation. Natural killer cell function was decreased in most patients despite a negative workup for p-HLH. Depending on disease severity, initial therapy included dexamethasone or dexamethasone and etoposide. Refractory patients were managed with blended regimens that included one or more of the following therapies: combination chemotherapy, alemtuzumab, emapalumab, and nivolumab. Rituximab did not appreciably decrease EBV viremia in most patients. Non-critically ill patients responded well to immunosuppressive therapy and are long-term survivors without undergoing allogeneic hematopoietic stem cell transplantation (HSCT). Alemtuzumab resulted in inflammation flare in two of the three patients. Three patients underwent allogeneic HSCT, with disease relapse noted in one. At a median follow-up of 3 years, 10 of the 15 patients are alive. Conclusion T cell-EBV-HLH occurs in the USA among the non-Asian populations, especially in those who are Hispanic.
\end{abstract}

Keywords EBV $\cdot$ Hemophagocytic lymphohistiocytosis $\cdot$ HLH $\cdot$ Epstein-Barr virus $\cdot$ T cells

Shanmuganathan Chandrakasan

Shanmuganathan.Chandrakasan@emory.edu

$1 \quad$ Aflac Cancer and Blood Disorders Center, Children's Healthcare of Atlanta and Department of Pediatrics, Emory University School of Medicine, Atlanta, GA, USA

2 Allergy and Clinical Immunology Unit, Department of Medicine, Hadassah Medical Organization, Faculty of Medicine, Hebrew University of Jerusalem, Jerusalem, Israel

3 Present Address: Center for Cancer and Blood Disorders, Phoenix Children's Hospital, AZ, Phoenix, USA

4 Aflac Cancer and Blood Disorders Center, Children's Healthcare of Atlanta, Atlanta, GA, USA

5 Department of Pathology, Children's Healthcare of Atlanta, Atlanta, GA, USA

\section{Introduction}

Hemophagocytic lymphohistiocytosis (HLH) is a rare and potentially life-threatening disorder. It is characterized by a cytokine storm of pro-inflammatory cytokines, resulting in a clinical presentation of fever, splenomegaly, hypofibrinogenemia, and coagulopathy [1].

Based on the underlying genetic basis, HLH can be classified as primary (p-HLH) or secondary. Genetic defects in $\mathrm{T}$ and natural killer (NK) cell degranulation and cytotoxicity lead to an abnormal inflammatory response and result in p-HLH; these include mutations in PRF1, UNC13D, STXBP2, STX11, LYST, and RAB27a [1-6]. Secondary HLH is usually triggered by underlying infectious, neoplastic, or autoimmune effectors. Epstein-Barr 
virus (EBV) is considered a common infectious inducer of secondary HLH (EBV-HLH) [1, 7].

In the vast majority of EBV-HLH in Western countries, B cells are the primary reservoir of EBV. Rituximab, an antiCD20 antibody, is an effective treatment for these patients [7].

However, there are several reports of fulminant EBV-HLH, in which EBV is primarily found in T and NK cells. This T cell-associated EBV-HLH (T cell-EBV-HLH) has predominantly been described in patients of East Asian origin, mainly from Japan and China [8-12]. The clinical course in the majority of these patients is usually fulminant and warrants urgent treatment and, in several cases, allogeneic hematopoietic stem cell transplantation (HSCT) [13, 14]. Reports of T cell-EBV-HLH phenotype among non-Asians are scarce [15].

In this study, we summarize our experience with T cellEBV-HLH in a cohort of 15 pediatric patients from the southeast United States (US). A detailed analysis of the immune profile, clinical course, and laboratory workup, including $\mathrm{T}$ cell activation profile and outcome, was conducted, along with a review of the corresponding literature.

\section{Materials and Methods}

\section{Patient Cohort}

A retrospective analysis of patients diagnosed with T cellEBV-HLH and were admitted to Children's Healthcare of Atlanta (CHOA; Georgia, USA) from 2010 to 2020 was conducted. The study was approved by the institutional review board. Diagnosis of HLH was made according to the HLH diagnostic criteria [2]. Baseline demographic and treatment characteristics, laboratory values, and outcomes were extracted from patients' electronic medical records. Race/ ethnicity was patient reported. Patients with p-HLH and macrophage activation syndrome (MAS), who were admitted to CHOA during the same period (2010-2020), were included, as a comparison cohort.

\section{Genetic Workup}

Results from gene panel testing were available for 12 patients and included the following genes: AP3B1, CD27, ITK, LYST, PRF1, RAB27A, SH2D1A, STX11, STXBP2, UNC13D (MUNC13-4), and XIAP (BIRC4). In some patients, a broader next-generation-based sequencing immune gene panel and whole exome sequencing were completed.

\section{EBV Identification}

Plasma EBV viremia was evaluated using polymerase chain reaction (PCR). EBV was demonstrated in T, B, and NK cells by PCR in sorted populations or by EBVencoded RNA (EBER)-in situ hybridization (ISH) staining of bone marrow with immunohistochemical staining for CD3 and PAX5. Due to sampling volume limitation in children, profound lymphopenia at presentation, and logistical reasons, we were not able to differentiate if the EBV in T cell predominantly affected CD4 or CD8 compartment. As per pathologist discretion, in a limited number of patients $(n=7), T$ cell clonality was evaluated by $T$-cell receptor gamma gene rearrangement studies. EBV serology consisting of IgG and IgM EBV viral capsid antigen (VCA), IgG EBV early antigen (EBV-EA), and IgG EBV nuclear antigen (EBNA) was also evaluated in some patients.

\section{Immune Workup}

Standard of care immune workup was performed at the Clinical Laboratory Improvement Amendments (CLIA)certified clinical laboratory of CHOA and at the diagnostic immunology laboratory at Cincinnati Children's Hospital Medical Center. Immune investigations consisted of lymphocyte subset analysis, perforin and granzyme B expression, CD107a degranulation assay, plasma soluble interleukin-2 receptor (SIL2R) levels, NK cell activity, and cytotoxic T lymphocyte (CTL) function.

In a limited number of patients (three p-HLH and three $\mathrm{T}$ cell-EBV-HLH), additional $\mathrm{T}$ cell immunophenotyping for the purposes of research was performed. Peripheral blood mononuclear cells (PBMCs) were stained with CD3-PerCP/Cy5.5, CD8-BUV395, CD45RA-APC, CCR7PE, HLA-DR-BV711, CD38-BUV496, and PD-1-BV421 antibodies (BD Biosciences and BioLegend). Live/dead fixable aqua dead cell stain (Thermo Fisher) was used to exclude dead cells in the analysis. Flow cytometry data was acquired on BD FACSymphony ${ }^{\mathrm{TM}} \mathrm{A} 5$ and analyzed using FlowJo software v10. Effector memory (EM) population of $\mathrm{CD}^{+} \mathrm{T}$ cells was identified as $\mathrm{CCR} 7^{-} \mathrm{CD} 45 \mathrm{RA}^{-} \mathrm{CD} 8^{+}$ $\mathrm{T}$ cells. Activated $\mathrm{CD} 8^{+} \mathrm{T}$ cells were identified as HLA$\mathrm{DR}^{+} \mathrm{CD} 38^{+}$gated on $\mathrm{CD} 8^{+} \mathrm{EM} \mathrm{T}$ cells or $\mathrm{CD} 8^{+} \mathrm{T}$ cells. Due to a lack of additional T-cell immunophenotypic data from infection-related HLH (iHLH) and MAS cohorts, our $\mathrm{T}$ cell activation analysis was restricted to $\mathrm{p}-\mathrm{HLH}$ and $\mathrm{T}$ cell-EBV-HLH. 


\section{Results}

\section{Clinical Characteristics of the Patients}

Clinical characteristics of the patients are summarized in Table 1. Fifteen patients (9 males, 6 females) with a mean age at presentation of 3.9 years (10 months-19 years) were included in the analysis. Eight of the 15 patients were less than 3 years of age. Twelve patients were non-Asian. Of these, nine patients were Hispanic, two were Caucasian, and one was African American. None of the patients had a family history of HLH. In 14 of the 15 patients, EBV-HLH was the presenting manifestation and only one patient had NK/T cell lymphoma preceding HLH diagnosis (patient (P)9). None of the patients in our cohort had a preceding history of chronic active EBV (CAEBV) infection. Nine patients required critical care for cardiorespiratory and hemodynamic support. Five patients presented with acute liver failure.

\section{Diagnostic Workup}

\section{HLH Workup of Peripheral Blood and Bone Marrow}

Peripheral blood analyses at diagnosis are presented in Table 2. Cytopenia in at least two cell lineages (hemoglobin $<9 \mathrm{~g} / \mathrm{dl}$, platelets $<100 \times 10^{3} / \mu \mathrm{l}$, neutrophils $<1 \times 10^{3} /$ $\mu \mathrm{l})$ was noted in 12 patients. Elevated hepatocellular enzymes were noted in all patients, and five presented with aspartate aminotransferase (AST) of $>1000 \mathrm{U} / \mathrm{l}$. Nine patients had significant coagulopathy with a fibrinogen level of $<100 \mathrm{mg} / \mathrm{dl}$. Elevated ferritin levels $(>500 \mu \mathrm{g} / \mathrm{l})$ were seen in all patients; all but one patient had ferritin levels of more than $5000 \mu \mathrm{g} / \mathrm{l}$. Bone marrow biopsies were performed in 13 of the 15 patients (Table 2). Hemophagocytosis was demonstrated in 12 out of 13 patients. Bone marrow cellularity was variable, with most being hypercellular.

\section{EBV Identification}

Plasma EBV viral load varied from 5094 to $>1,000,000 \mathrm{IU} /$ $\mathrm{ml}$ at presentation (Table 3 ). The EBV serology profile revealed positive IgM VCA and negative IgG EBNA in most of the patients tested (Table 3). Also, more than half of the patients were less than 3 years of age at disease onset; hence, the EBV in these patients is likely to be a primary or early infection. In the majority, EBV was demonstrated in T cells by PCR in sorted populations. In others, EBER-ISH staining of bone marrow in the $\mathrm{CD}^{+} \mathrm{T}$ cell region was used to diagnose T cell-EBV-HLH (Fig. 1, Table 3 ). T cell clonality studies revealed clonal or oligoclonal $\mathrm{T}$ cells in all patients tested (Table 3 ).

\section{Genetic Workup}

Gene panel testing for known p-HLH genes did not show pathologic defects in 10 out of 12 patients tested. One patient was found to be a $P R F$ single-allele carrier, and

Table 1 Clinical characteristics of patients with T cell-EBV-HLH

\begin{tabular}{|c|c|c|c|c|c|c|c|}
\hline \multirow{2}{*}{$\begin{array}{l}\text { Patient } \\
\text { number }\end{array}$} & \multirow[t]{2}{*}{ Gender } & \multirow[t]{2}{*}{ Ethnic background* } & \multirow[t]{2}{*}{ Family history } & \multirow[t]{2}{*}{ Age at presentation (years) } & \multicolumn{3}{|c|}{ Clinical presentation } \\
\hline & & & & & Fever $\geq 38.5^{\circ} \mathrm{C}$ & Splenomegaly & Coagulopathy \\
\hline 1 & M & Caucasian & No & 4.9 & Yes & Yes & Yes \\
\hline 2 & $\mathrm{~F}$ & Hispanic & No & 7.0 & Yes & Yes & Yes \\
\hline 3 & $\mathrm{~F}$ & Hispanic & No & 1.0 & Yes & Yes & Yes \\
\hline 4 & $\mathrm{~F}$ & East Asian & No & 2.1 & Yes & Yes & No \\
\hline 5 & M & Hispanic & No & 2.2 & Yes & Yes & No \\
\hline 6 & $\mathrm{~F}$ & Hispanic & No & 7.0 & Yes & Yes & Yes \\
\hline 7 & M & East Asian & No & 4.8 & Yes & Yes & Yes \\
\hline 8 & M & Caucasian & No & 19.0 & Yes & Yes & Yes \\
\hline 9 & M & Hispanic & No & 15.0 & Yes & Yes & Yes \\
\hline 10 & $\mathrm{~F}$ & Hispanic & No & 1.0 & Yes & Yes & No \\
\hline 11 & M & Hispanic & No & 1.0 & Yes & Yes & Yes \\
\hline 12 & M & Hispanic & No & 3.0 & Yes & Yes & Yes \\
\hline 13 & $\mathrm{~F}$ & Hispanic & No & 19.0 & Yes & Yes & No \\
\hline 14 & M & AA & No & 0.8 (10 months) & Yes & Yes & Yes \\
\hline 15 & M & East Asian & No & 0.9 (11 ${ }^{\circ}$ months $)$ & Yes & Yes & Yes \\
\hline
\end{tabular}

*Self-identified

$M$ male, $F$ female, $A A$ African American 


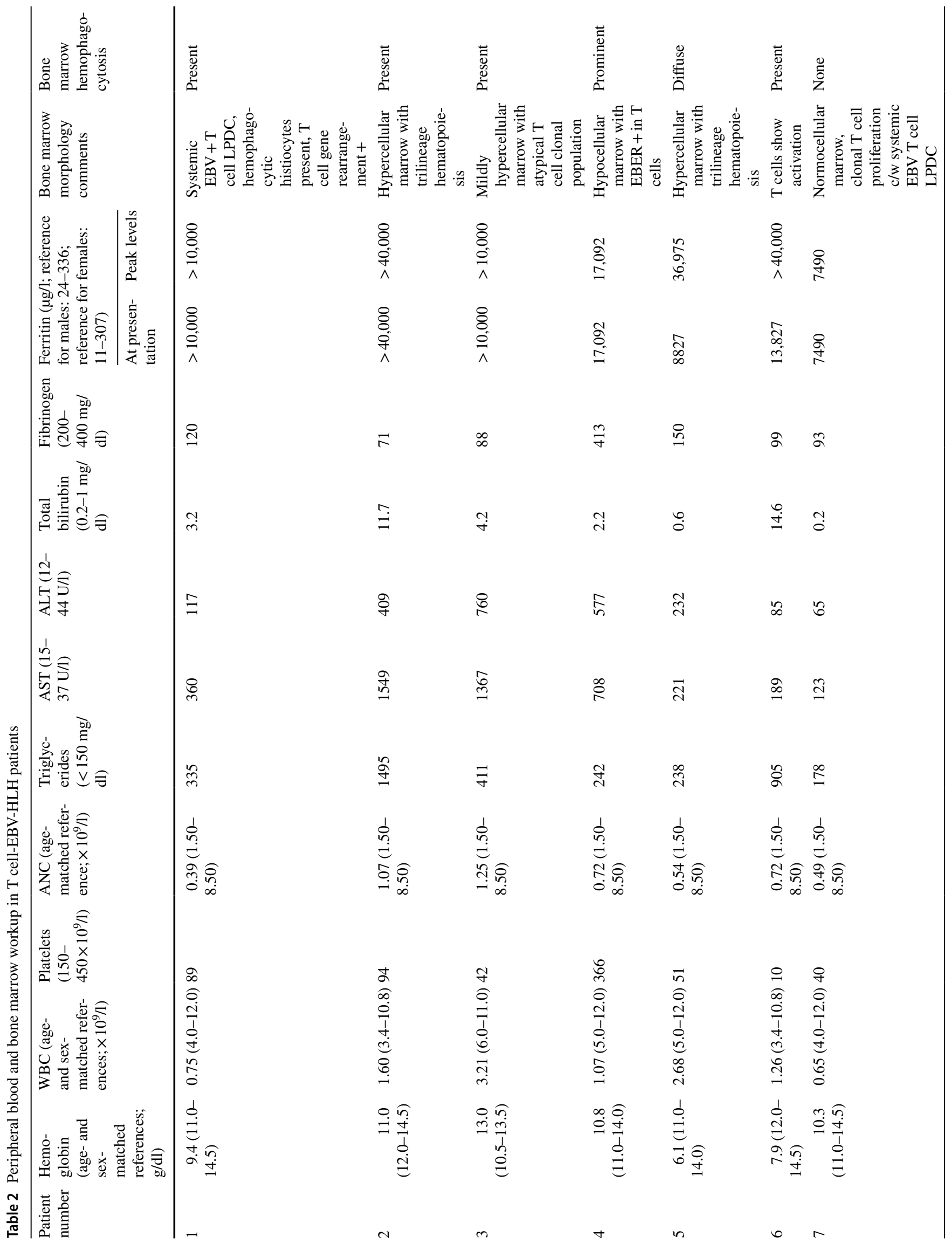




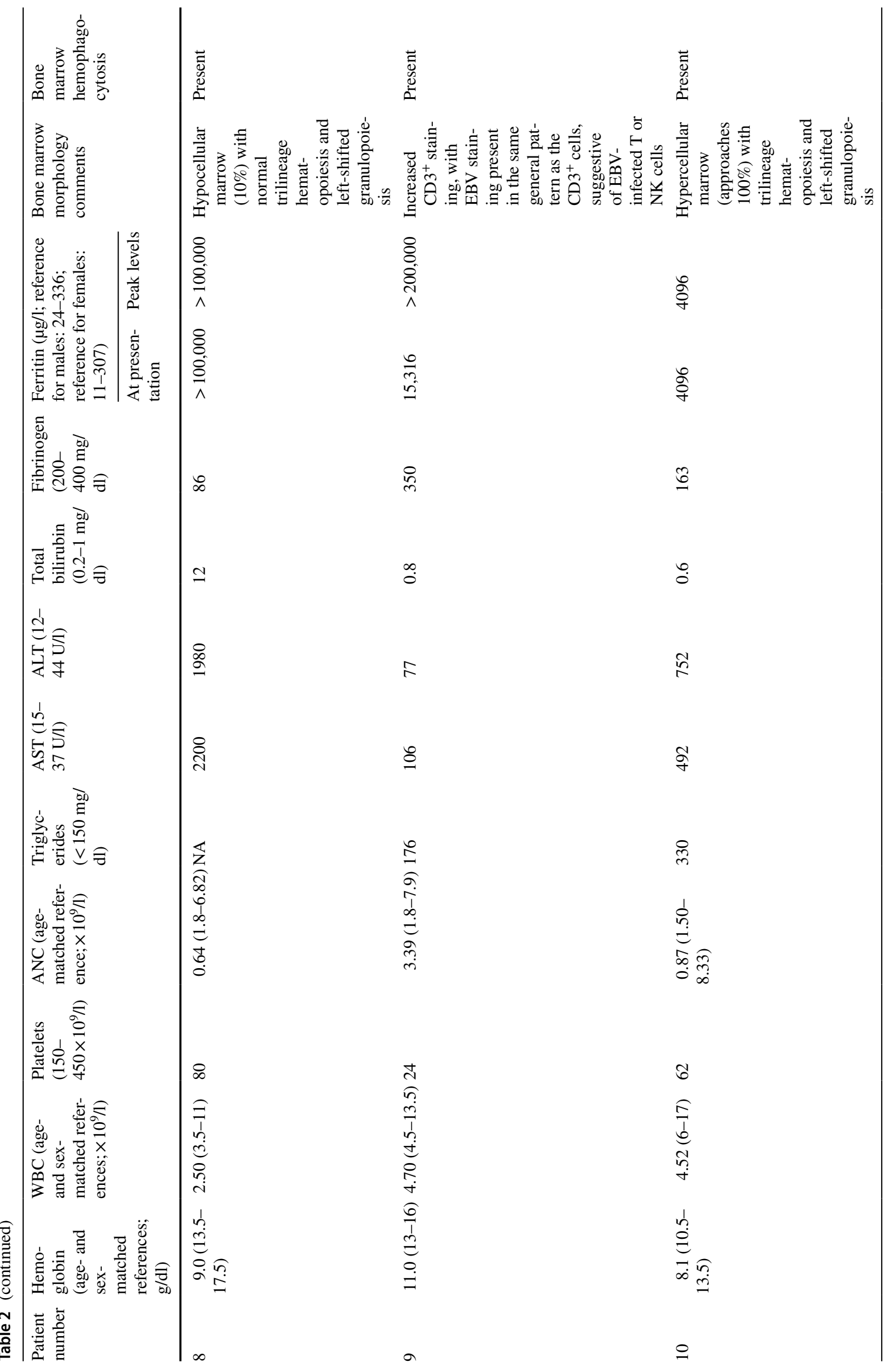




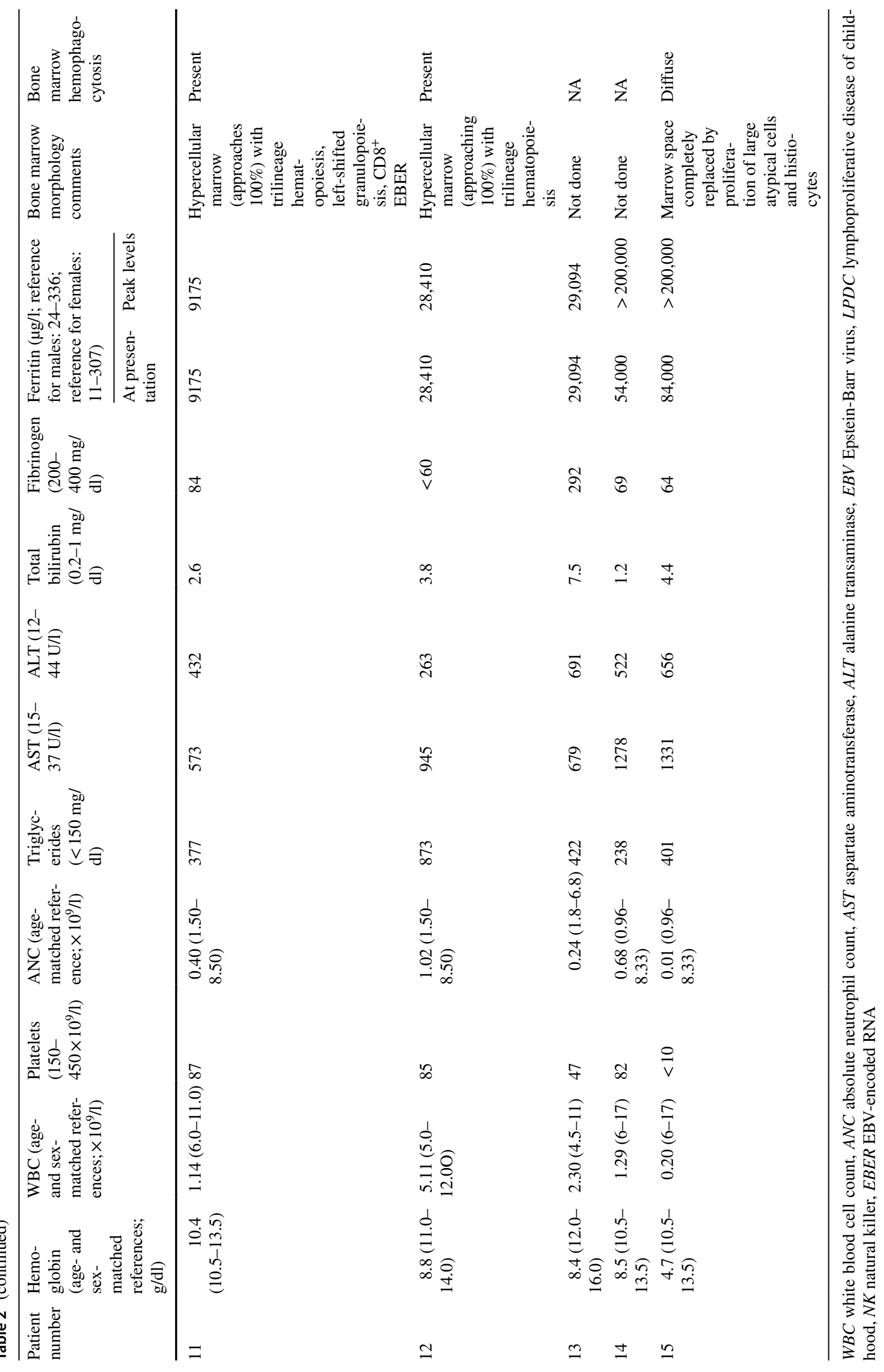


another patient had two variants of unknown significance in $R A B 27 a$ (Table 4).

\section{Immune Workup}

Results of the immune workup are presented in Table 4. Median SIL2R levels were markedly increased in all patients. SIL2R levels from T cell-EBV-HLH patients were compared to SIL2R levels from other HLH patients diagnosed during the same period. We noted that the SIL2R levels in patients with T cell-EBV-HLH $(20,251 \pm 11,318 \mathrm{U} /$ $\mathrm{ml}$ ) were comparable to the levels in those with p-HLH $(25,679 \pm 16,837 \mathrm{U} / \mathrm{ml})$. Additionally, patients with $\mathrm{T}$ cell-EBV-HLH had significantly higher SIL2R levels than forms of infection-driven HLH $(4339 \pm 2048 \mathrm{U} /$ $\mathrm{ml} ; p<0.01)$ or rheumatologic disease-associated HLH (MAS) $(4727 \pm 4396 \mathrm{U} / \mathrm{ml} ; p<0.001$; Fig. 2A). Additionally, T cell-EBV-HLH patients, who were critically ill and needed intensive care management at presentation, had higher SIL2R when compared to non-critically ill $\mathrm{T}$ cellEBV-HLH patients $(27,072 \pm 11,108$ vs. $12,284 \pm 4279 \mathrm{U} /$ $\mathrm{ml} ; p<0.05$; Fig. 2B).

Direct $\mathrm{T}$ cell activation markers were evaluated in three consecutive patients with T cell-EBV-HLH (P13-P15). Similar to $\mathrm{p}-\mathrm{HLH}, 70-95 \%$ of EM CD8 ${ }^{+}$showed activation with high HLA-DR and CD38 expression (Fig. 3). Further, both T cell-EBV-HLH and p-HLH patients had high expression of PD-1 in EM CD8 ${ }^{+}$T cells, suggesting upregulation of co-inhibitory PD-1 in the setting of marked T cell activation (Fig. 4).

CD4/CD8 ratio was $<1$ in 9 out of 11 patients, suggesting a relative expansion of $\mathrm{CD}^{+} \mathrm{T}$ cells. NK cell activity was reported in six patients and was decreased or absent in five patients. CTL function was available for three patients (P8, P10, and P11) and was decreased in one patient (P11). Perforin and granzyme B expression testing was performed in 12 patients, but two patients had inadequate NK cells to adequately evaluate expression. Of the 10 evaluable patients, perforin and/or granzyme B was elevated in all the patients (Table 4). There was a mild decrease in perforin expression in one patient, though the perforin genotype was normal. CD107a degranulation was normal in five of the seven patients evaluated.

\section{Treatment and Outcome}

Treatment and outcome information is listed in Table 5. Dexamethasone was given to all the patients. Patient also received etoposide $(n=11)$, cyclosporine $\mathrm{A}(n=3)$, rituximab $(n=12)$, alemtuzumab $(n=3)$, emapalumab $(n=2)$, nivolumab $(n=2)$, and anakinra $(n=1)$. In many patients, when EBV was identified, rituximab was empirically administered by the treating team with the clinical assumption that EBV is predominantly in the B cell compartment. However, after identification of EBV in T cell, further, rituximab was usually held. Intravenous immunoglobulin was given as part of supportive management for all patients.

Nine patients required intensive care unit (ICU) admission. All six patients who did not require ICU care were alive at the date of last contact. Of the nine patients needing ICU care, three had hemodynamic shock, five presented with acute liver failure, and three had respiratory distress. Among them, four are alive. At a median follow-up of 3 years, the overall survival was $66.6 \%$. No relationship between disease severity and EBV load at presentation was apparent. EBV viremia decreased in all patients with initiation of $T$ cell-directed therapy (dexamethasone and/or etoposide), and the addition of rituximab did not result in an appreciable decrease in EBV viremia.

Four of the six non-critically ill patients received dexamethasone alone or in combination with rituximab. This therapy led to complete remission in all four patients. All critically ill patients admitted to ICU $(n=9)$ and two non-critically ill patients were initially started on a regimen containing dexamethasone and etoposide $(n=11)$, as per HLH-94/2004 protocol [16]. Though there was an initial response in all patients, five patients had either inadequate disease control or disease recurrence. A chemotherapy regimen of CHOP (cyclophosphamide, doxorubicin, vincristine, and prednisone) $(n=2)$ or EPOCH (etoposide, vincristine, doxorubicin, cyclophosphamide, and prednisone) $(n=1)$ was used in patients refractory to etoposide and resulted in partial disease control. Alemtuzumab was used in three patients- two of these patients subsequently had worsening of EBV viremia and elevation of ferritin. The combination of emapalumab and nivolumab was used in two patients with refractory disease; one patient had no significant response while the other had a partial response.

All nine critically ill patients and one patient with persistent low-level EBV viremia after HLH control were initially evaluated for HSCT. Of these ten patients, three achieved complete remission with conventional HLH therapy and cleared EBV viremia and therefore did not proceed to HSCT. Four of the ten patients died before undergoing HSCT, and three patients underwent HSCT. Of the three patients, one is a long-term survivor (P8), one is in the immediate postHSCT period (P15), and one died of post-HSCT complications (P9). P9 developed graft versus host disease, adenoviremia, EBV reactivation, and refractory HLH despite $100 \%$ of donor T cells. For patients who did not undergo HSCT, causes of death included intracranial bleeding, refractory adenoviremia and EBV reactivation (P2), refractory HLH disease (P4), intracranial bleeding associated with coagulopathy (P6), and refractory disease complicated by SARS-CoV2 (P14). 
Table 3 EBV profile of the patients' cohort

\begin{tabular}{|c|c|c|c|c|c|c|c|c|}
\hline $\begin{array}{l}\text { Patient } \\
\text { number }\end{array}$ & $\begin{array}{l}\text { EBV viremia } \\
\text { load }(\mathrm{IU} / \mathrm{ml})^{*}\end{array}$ & EBV VCA IgG & EBV VCA IgM & EBV EA IgG & EBNA IgG & $\begin{array}{l}\text { Status of EBV } \\
\text { infection }\end{array}$ & Clonality** & $\begin{array}{l}\mathrm{EBV}+\text { cell } \\
\text { fraction*** }\end{array}$ \\
\hline 1 & 88,200 & NA & NA & NA & NA & NA & Clonal T & $\mathrm{T}$ cells \\
\hline 2 & 951,060 & +++ & +++ & ++ & - & $\begin{array}{l}\text { Primary/early } \\
\text { infection }\end{array}$ & Clonal T & $\mathrm{T}$ cell \\
\hline 3 & 110,000 & +++ & - & - & ++++ & Reactivation & Clonal T & $\mathrm{T}$ cell \\
\hline 4 & 138,930 & NA & NA & NA & NA & NA & NA & $\mathrm{T}$ cell \\
\hline 5 & $175,300^{\#}$ & ++++ & ++++ & ++ & - & $\begin{array}{l}\text { Primary/early } \\
\text { infection }\end{array}$ & NA & $\mathrm{T}$ cells \\
\hline 6 & $5094^{\#}$ & ++ & + & + & ++ & $\begin{array}{l}\text { Primary/early } \\
\text { infection }\end{array}$ & NA & $\mathrm{T}$ cells \\
\hline 7 & 156,000 & + & + & - & - & $\begin{array}{l}\text { Primary/early } \\
\text { infection }\end{array}$ & Clonal T & $\mathrm{T}$ cells \\
\hline 8 & $>1,000,000$ & NA & NA & NA & NA & NA & NA & $\mathrm{T}$ cells \\
\hline 9 & $>1,000,000$ & ++++ & - & ++ & + & $\begin{array}{l}\text { Primary/early } \\
\text { infection }\end{array}$ & NA & $\mathrm{T}$ cells \\
\hline 10 & $>1,000,000$ & + & + & - & - & $\begin{array}{l}\text { Primary/early } \\
\text { infection }\end{array}$ & NA & $\mathrm{T}$ and $\mathrm{B}$ cells \\
\hline 11 & 320,797 & ++ & ++ & - & + & $\begin{array}{l}\text { Primary/early } \\
\text { infection }\end{array}$ & Clonal T & $\mathrm{T}$ cells \\
\hline 12 & 221,488 & NA & NA & NA & NA & NA & Oligoclonal $\mathrm{T}$ & $\mathrm{T}$ and $\mathrm{B}$ cells \\
\hline 13 & 68,825 & - & + & - & - & $\begin{array}{l}\text { Primary/early } \\
\text { infection }\end{array}$ & NA & $\mathrm{T}$ and $\mathrm{B}$ cells \\
\hline 14 & $>1,000,000$ & NA & NA & NA & NA & NA & NA & $\mathrm{T}$ and NK cells \\
\hline 15 & $>1,000,000$ & NA & NA & NA & NA & NA & Clonal T & $\mathrm{T}$ cells \\
\hline
\end{tabular}

$E B V$ Epstein-Barr virus, $V C A$ viral capsid antigen, $E B V E A$ EBV early antigen, $E B N A$ EBV nuclear antigen, $N K$ natural killer, $N A$ data is not available

*EBV viral load at presentation

${ }^{\#}$ EBV viral load increased to $>1,000,000 \mathrm{IU} / \mathrm{ml}$ during the disease course

**T cell clonality assessed by $\mathrm{T}$ cell receptor gamma gene rearrangement

***EBV-positive cell fraction evaluated by either sorted PCR or EBER ISH

\section{Discussion}

We describe 15 children of various racial and ethnic backgrounds with T cell-EBV-HLH. East Asian populations have previously been reported to have a high incidence of T cellEBV-HLH and T/NK cell-mediated EBV-lymphoproliferative disorder (LPD) $[10,13,17,18]$. In our cohort, nine of the 15 patients were Hispanic, suggesting that $\mathrm{T}$ cellEBV-HLH may be under recognized in this group. Limited reports exist on the prevalence of $\mathrm{T}$ and NK cell-based EBVLPD disorders in patients of Central and South American backgrounds [19-21]. Beutel et al. [15] described seven German patients with T cell-EBV-HLH. Our study demonstrates that T cell-EBV-HLH can be found in Caucasian and African American patients as well, albeit at a lesser frequency. Recent reports of hydroa vacciniforme-like LPD in Caucasians are suggestive that T cell-EBV-LPD can also be seen in Caucasians [22]. The clinical spectrum of T/NK cell-mediated EBV-LPD is broad [18, 21]. In our study, majority had HLH as the presenting manifestation of underlying EBV-driven LPD. Only one had history of NK/T cell lymphoma, and none had history of CAEBV infection.

The reason why $\mathrm{T}$ cell-EBV-HLH is more common in East Asian and Hispanic populations is not apparent, and the genetic basis is not well defined. Though monogenic diseases associated with increased EBV susceptibility are identified, most tend to involve EBV affecting the B cell compartment [23-26]. In our cohort, evaluation for classical p-HLH genetic defects was negative in most patients. One patient had two $R A B 27 a$ variants in trans along with a decrease in CD107a degranulation, suggesting there might have been a component of CTL defect similar of p-HLH. Though the vast majority of atypical T/NK cell-based EBVLPD has no known monogenetic defects, case reports allude to the presence of a classical cytotoxic pathway defect in some patients $[8,27]$.

NK cell function was noted to be decreased in five of the six patients tested. This is despite having a higher expression of perforin and granzyme $\mathrm{B}$ in the majority of the tested patients. Degranulation was also noted to be decreased 
Fig. 1 A The core biopsy demonstrates a marrow space completely replaced by a proliferation of large, atypical cells and histiocytes. Background hematopoiesis is markedly decreased. B An EBV (EBER) in situ hybridization demonstrates markedly increased staining in the core biopsy. C PAX5 stain highlights rare small B cells. D A CD3 stain highlights numerous cells throughout the infiltrate, including large cells, and the EBER staining appears to correspond to a subset of $\mathrm{CD}^{+} \mathrm{T}$ cells
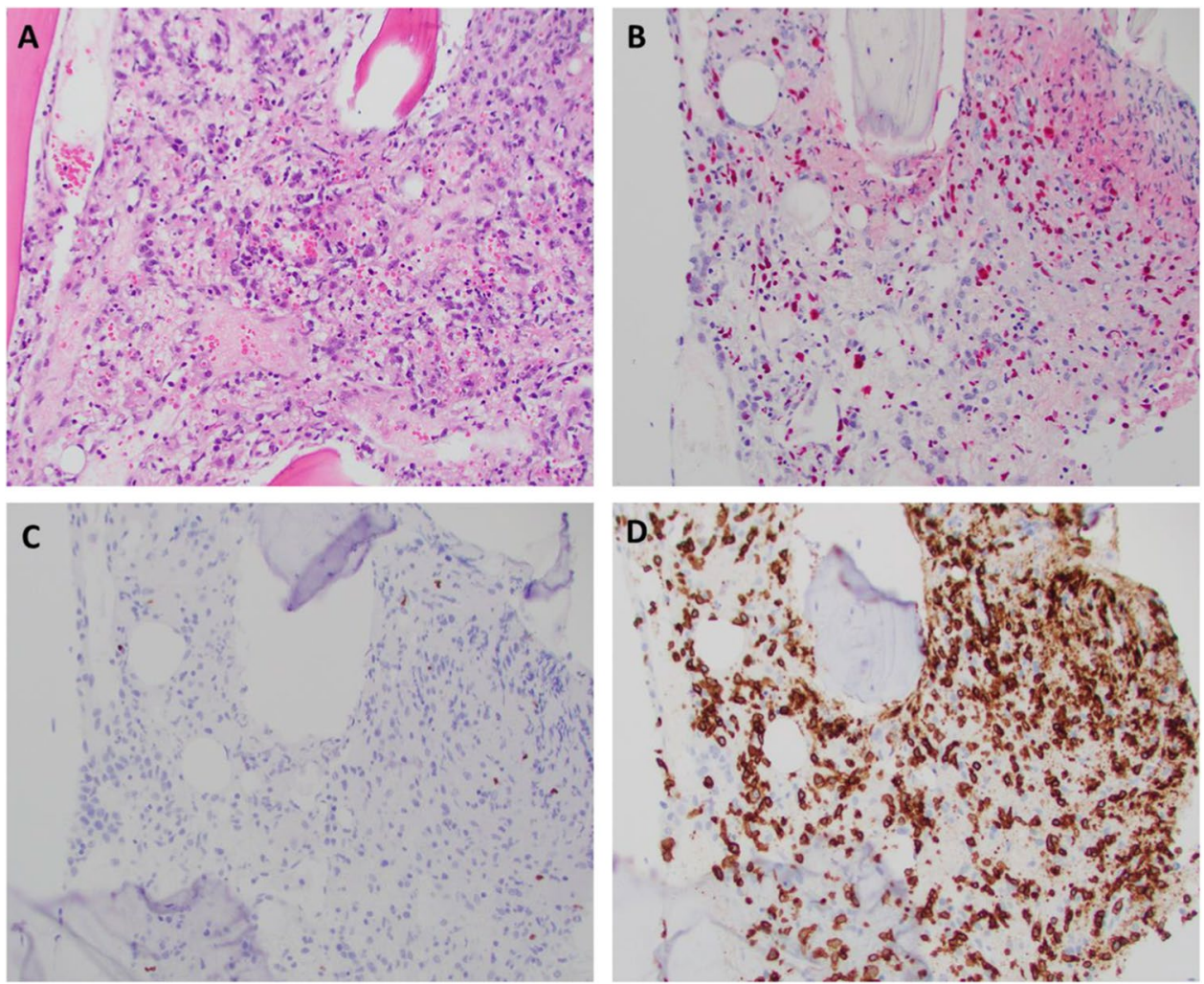

in some patients, suggesting there could be an acquired degranulation defect due to EBV infection of T cells in some patients with T cell-EBV-HLH. The findings of decreased NK cell cytotoxicity and decreased degranulation could be due to EBV-induced alterations such as immune exhaustion, acquired defects in degranulation, co-stimulation, and cytotoxicity [28]. Interestingly, we found that in two of the three tested patients, CTL cytotoxicity assessed against EBVimmortalized B cells showed normal cytotoxicity. In our limited patient data, we have shown both T cell-EBV-HLH and p-HLH have high PD-1 expression. Increased PD-1 may not be a primary phenomenon and is likely a marker of activation. Since treatment with PD-1 inhibitors in T cellEBV-HLH was shown to result in improvement in EBV load and HLH [28], upregulation might be an acute counter-regulatory mechanism following activation, but if persistent, it could result in additional $\mathrm{T}$ cell dysfunction.

Utilizing T cell activation biomarker, SIL2R, and direct T cell activation markers such as HLA-DR and CD38, we have shown that the amplitude of $\mathrm{T}$ cell activation in patients with T cell-EBV-HLH was comparable to patients with p-HLH [29]. When compared to other forms of secondary HLH, such as other infections associated with HLH and MAS, the extent of $\mathrm{T}$ cell immune activation is significantly higher. These findings suggest that despite the absence of classical genetic defects in granule-mediated cytotoxicity, the amplitude of $\mathrm{T}$ cell activation in T cell-EBV-HLH is similar to that seen in
p-HLH. Higher acuity, morbidity, and mortality in T cellEBV-HLH when compared to other infections associated with HLH or MAS could be, in part, due to higher T cell activation noted in this form of HLH. Transient suppression of EBV-induced NK and T cell cytotoxic functions could lead to a hyper-inflammatory state similar to that seen in p-HLH.

EBV PCR flow in sorted cell populations is a more definitive modality to identify T cell-EBV-HLH. However, an alternate strategy, such as dual staining for $\mathrm{CD} 3$ and EBER and EBER flow FISH [30], could also help establish EBV infection of $\mathrm{T}$ cells. The findings of persistently high EBV viral load despite empiric rituximab could also offer a clue to practitioners that EBV may not be predominantly in the B cell compartment. Differentiating this from B cellEBV-HLH is critical, as most B cell-EBV-HLH responds to rituximab-based treatment regimens [31]. In contrast, $\mathrm{T}$ cellEBV-HLH usually has a poor response to rituximab. In our cohort, EBV clearance in some patients was achieved with $\mathrm{T}$ cell-directed therapy alone without using rituximab. As rituximab holds a possible risk of post-treatment persistent hypogammaglobulinemia and recurrent infections [32], its use could be restricted to B cell-EBV-HLH.

Alemtuzumab, a monoclonal anti-CD52 antibody which causes mature $\mathrm{T}$ cell depletion, was suggested as a reasonable salvage therapy for HLH [33]. Two patients in our cohort had clinical deterioration while receiving alemtuzumab therapy. The mechanism for this 
Table 4 Immune workup of T cell-EBV-HLH patients

\begin{tabular}{|c|c|c|c|c|c|c|c|}
\hline $\begin{array}{l}\text { Patient } \\
\text { number }\end{array}$ & $\begin{array}{l}\mathrm{CD}^{+} / \mathrm{CD}^{+} \\
\text {(age-matched } \\
\text { reference) }\end{array}$ & NK cell activity & $\begin{array}{l}\text { Primary HLH } \\
\text { gene mutation }\end{array}$ & $\begin{array}{l}\text { Soluble IL-2 } \\
\text { receptor }(\mathrm{U} / \mathrm{ml} \text {; } \\
\text { age-matched } \\
\text { reference) }\end{array}$ & $\begin{array}{l}\text { CD107a (\%; } \\
\text { age-matched } \\
\text { reference) }\end{array}$ & $\begin{array}{l}\text { Perforin/gran- } \\
\text { zyme B }\end{array}$ & CTL function \\
\hline 1 & NA & Absent & Negative & $15,221(\leq 2126)$ & NA & $\begin{array}{l}\text { Increased expres- } \\
\text { sion of perforin } \\
\text { and granzyme B } \\
\text { in NK cells }\end{array}$ & NA \\
\hline 2 & $0.63(0.8-5.0)$ & NA & Negative & $26,709(45-1105)$ & NA & $\begin{array}{l}\text { Increased gran- } \\
\text { zyme B expres- } \\
\text { sion in NK cells }\end{array}$ & NA \\
\hline 3 & NA & Normal & Negative & $\begin{array}{l}11,605(334- \\
3026)\end{array}$ & NA & $\begin{array}{l}\text { Not accurate due } \\
\text { to the insuffi- } \\
\text { cient number of } \\
\text { NKT cells }\end{array}$ & NA \\
\hline 4 & NA & NA & NA & $>6500(<970)$ & NA & NA & NA \\
\hline 5 & $0.91(0.8-5.0)$ & NA & Negative & $12,329(\leq 2126)$ & $7(11-35)$ & $\begin{array}{l}\text { Increased expres- } \\
\text { sion of perforin } \\
\text { and granzyme B } \\
\text { in NK cells }\end{array}$ & NA \\
\hline 6 & $1.27(0.8-5.0)$ & NA & Negative & $33,305(45-1105)$ & Normal & $\begin{array}{l}\text { Increased expres- } \\
\text { sion of perforin } \\
\text { and granzyme B } \\
\text { in NK cells }\end{array}$ & NA \\
\hline 7 & NA & Decreased & NA & $26,376(\leq 2126)$ & NA & $\begin{array}{l}\text { Not accurate due } \\
\text { to the insuffi- } \\
\text { cient number of } \\
\text { NKT cells }\end{array}$ & NA \\
\hline 8 & $0.90(0.8-5)$ & Decreased & VUS in $R A B 27 a$ & NA (45-1105) & $7(11-35)$ & NA & Normal \\
\hline 9 & $0.53(0.8-5)$ & Decreased & Negative & $18,414(45-1105)$ & $16(11-35)$ & $\begin{array}{l}\text { Increased expres- } \\
\text { sion of perforin } \\
\text { and granzyme B } \\
\text { in NK cells }\end{array}$ & NA \\
\hline 10 & $1.41(1.2-6.6)$ & Decreased & Negative & $\begin{array}{l}10,887(334- \\
3026)\end{array}$ & $10(11-35)$ & $\begin{array}{l}\text { Increased expres- } \\
\text { sion of perforin } \\
\text { and granzyme B } \\
\text { in NK cells }\end{array}$ & Normal \\
\hline 11 & $2.46(1.2-6.6)$ & NA & $\begin{array}{l}P R F \text { single-allele } \\
\text { carrier }\end{array}$ & $\begin{array}{l}18,066(334- \\
3026)\end{array}$ & $11(11-35)$ & $\begin{array}{l}\text { Increased expres- } \\
\text { sion of perforin } \\
\text { and granzyme B } \\
\text { in NK cells }\end{array}$ & $\begin{array}{l}\text { Decreased to } \\
\text { absent }\end{array}$ \\
\hline 12 & $0.14(0.8-5.0)$ & NA & Negative & $5422(\leq 2126)$ & $21(11-35)$ & $\begin{array}{l}\text { Decreased expres- } \\
\text { sion of perforin } \\
\text { in NK cells } \\
\text { and increased } \\
\text { expression of } \\
\text { granzyme B in } \\
\text { NK cells }\end{array}$ & NA \\
\hline 13 & $0.61(0.8-5.0)$ & NA & Negative & $11,849(137-838)$ & NA & $\begin{array}{l}\text { Increased } \\
\text { expression of } \\
\text { granzyme B in } \\
\text { NK cells }\end{array}$ & NA \\
\hline 14 & $0.76(0.8-5.0)$ & NA & Negative & $\begin{array}{l}26,370(334- \\
3026)\end{array}$ & NA & $\begin{array}{l}\text { Increased expres- } \\
\text { sion of perforin } \\
\text { and granzyme B } \\
\text { in NK cells }\end{array}$ & NA \\
\hline 15 & $0.61(0.8-5.0)$ & NA & NA & $\begin{array}{l}46,723(334- \\
3026)\end{array}$ & NA & NA & NA \\
\hline
\end{tabular}

$N A$ data is not available, $N K$ natural killer, $H L H$ hemophagocytic lymphohistiocytosis, $C T L$ cytotoxic T lymphocytes, VUS variant of unknown significance, $I L$ interleukin 
Fig. 2 A SIL2R levels of patients with p-HLH, T cellEBV-HLH, infection-driven HLH (i-HLH), and MAS. SIL2R levels are markedly increased in all the patients with T cell-EBV-HLH and are comparable to those in patients with p-HLH. SIL2R levels in T cell-EBV-HLH are increased, as compared to i-HLH $(* * p<0.01)$ and MAS $(* * * p<0.001)$. B A comparison between critically ill and non-critically ill patients with T cell-EBV-HLH. T cell-EBV-HLH patients, who are critically ill at presentation, had higher SIL2R levels when compared to the non-critically ill group $\left({ }^{*} p<0.05\right)$
A

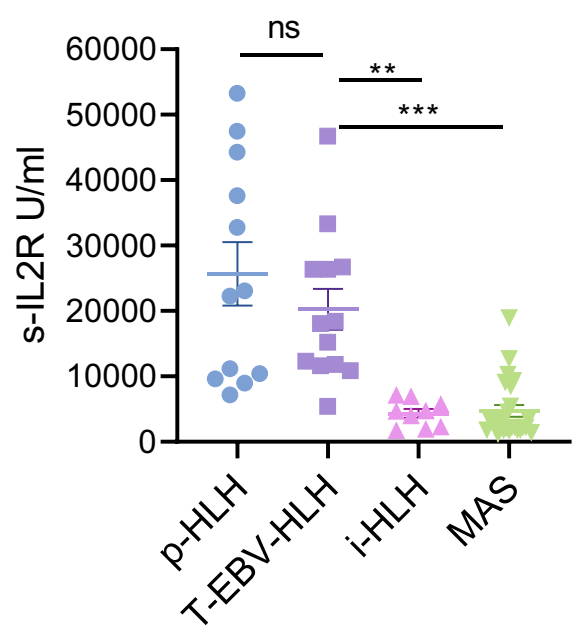

B T-EBV-HLH

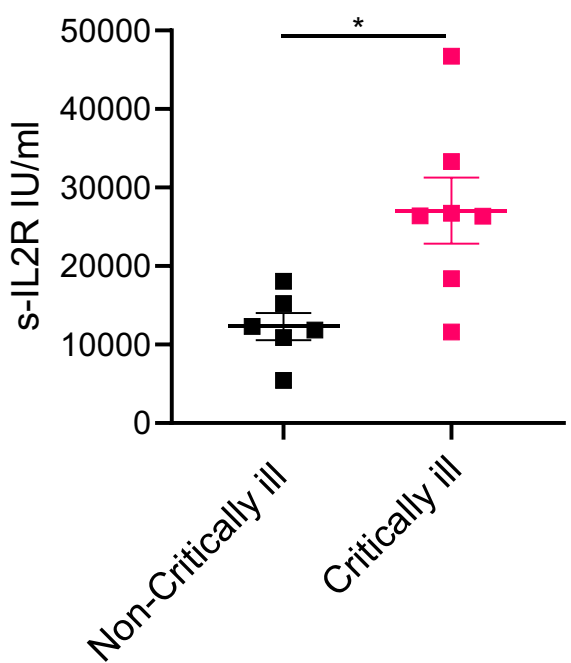

observation remains unknown. A recent report by Liu et al. [28] demonstrated the efficacy of nivolumab in patients with relapsed/refractory T cell-EBV-HLH. It is important to note that only two of the seven patients in that cohort had SIL2R $>2000 \mathrm{U} / \mathrm{ml}$. Similarly ferritin of more than $2000 \mathrm{ng} / \mathrm{ml}$ was noted in only two of the seven patients [28]. Based on this observation, it appears that Liu et al. [28] used nivolumab in EBV-HLH patients with only modest immune activation. In our patients, relapse or recurrence was characterized by a rapid increase in SIL2R to more than $20,000 \mathrm{U} / \mathrm{ml}$, and in many, ferritin was $>100,000 \mathrm{ng} / \mathrm{ml}$. The overwhelming immune activation might be the reason why nivolumab did not have a favorable response in our patient.

In our cohort, patient's refractory to etoposide responded to combination chemotherapy regimens consisting of cyclophosphamide and doxorubicin. It is hard to predict which $\mathrm{T}$ cell-EBV-HLH patients need aggressive therapy, including etoposide and/or a combination chemotherapy followed by HSCT, and which patients could receive a milder immune modulation and expectant management. It is worth noting that unlike most patients with CAEBV infection who require HSCT for a definitive cure, a significant proportion of patients with T cell-EBV-HLH can remain in remission without proceeding to HSCT. This finding that a proportion of patients with T cell-EBV-HLH can do well without needing HSCT aligns with similar findings by Sawada and Inoue [14] in Japanese patients. The biological basis for the difference in long-term management of T cell-EBV-HLH and CAEBV infection is still poorly understood. However, it is known that in T cell-EBV-HLH, the cellular target for $\mathrm{EBV}$ is usually $\mathrm{CD} 8^{+} \mathrm{T}$ cells compared to $\mathrm{CD} 4^{+} \mathrm{T}$ cells in
CAEBV infection [34, 35]. Thus, the management of all $\mathrm{T} /$ NK cell-based EBV-LPD is not the same.

In our study, the acuity of presentation seems to be an important predictor of long-term outcome in T cell-EBVHLH. Patients who are not critically ill at presentation needed less immune modulation and had an excellent longterm survival without needing HSCT. Additionally, even among those presenting with high disease acuity and critical illness, a significant proportion of patients are long-term survivors without HSCT. It is important to note that one patient had a relapse of EBV-HLH despite having $100 \%$ of donor cells in $\mathrm{T}$ cell compartment.

Despite this being one of the largest cohorts of T cellEBV-HLH in non-Asian children, the single-center experience and retrospective nature of the study limit its generalizability. Larger, prospective multi-institutional studies are needed to understand the biological basis and risk factors and define treatment paradigms for this potentially fatal disorder.

In conclusion, this study provides a detailed description of non-Asian patients with T cell-EBV-HLH in the USA, highlighting the presence of this disease in patients from a variety of racial and ethnic backgrounds. We also show that the amplitude of $\mathrm{T}$ cell activation in patients with $\mathrm{T}$ cell-EBV-HLH is similar to that in patients with p-HLH. Therefore, early diagnosis of T cell-EBV-HLH is critical. Staged management based on the acuity of initial presentation and response-based escalation of therapy, including HSCT, is also warranted. Non-critically ill patients, who responded well to initial immunosuppressive therapy, may not need HSCT. Patients, who are refractory to combination chemotherapy or other salvage therapies, experience high mortality, and emergent allogeneic HSCT may 


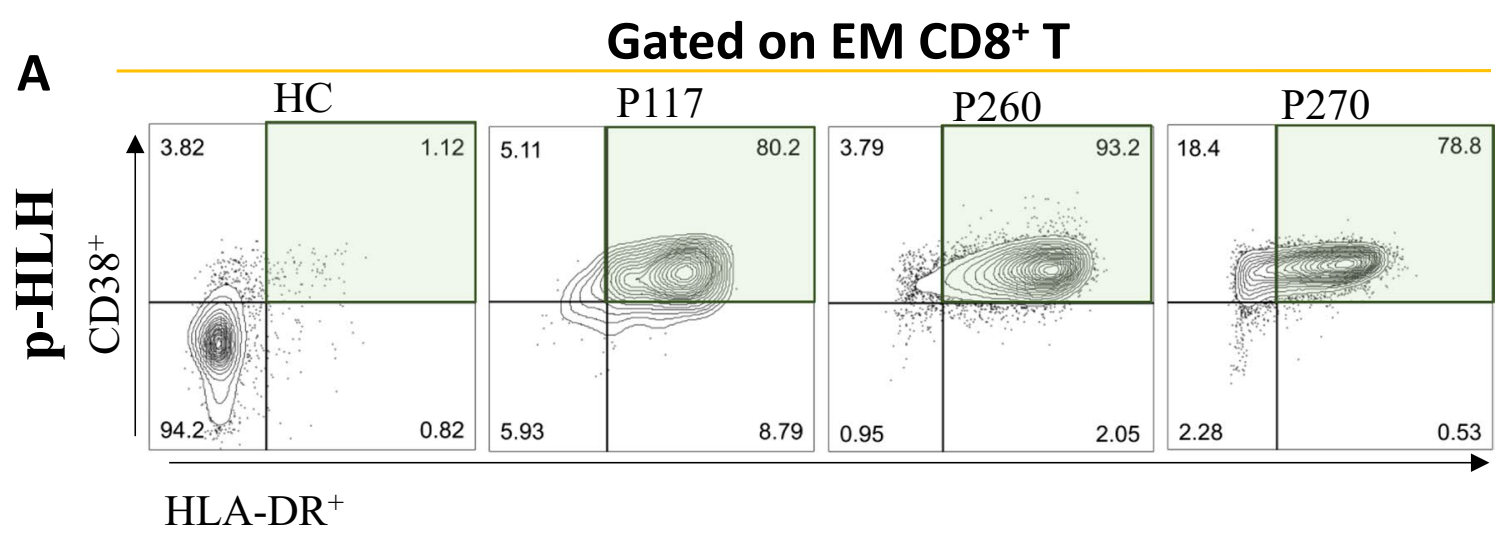

B

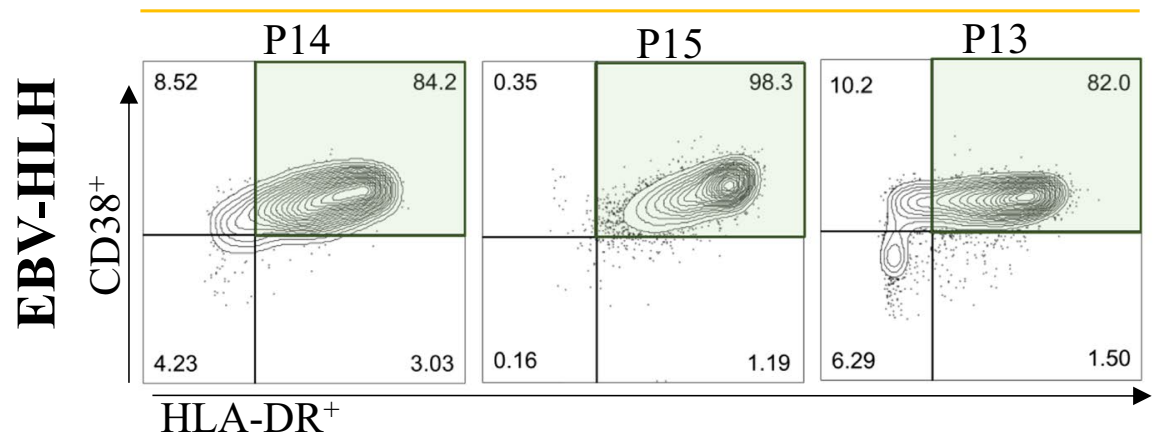

C Gated on $\mathrm{EM} \mathrm{CD8}{ }^{+} \mathrm{T}$

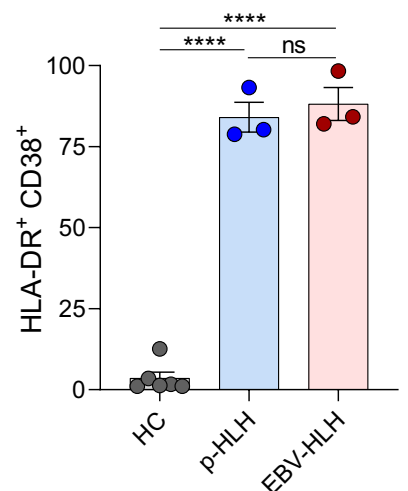

D

Gated on $\mathrm{CD}^{+}{ }^{\mathbf{T}}$
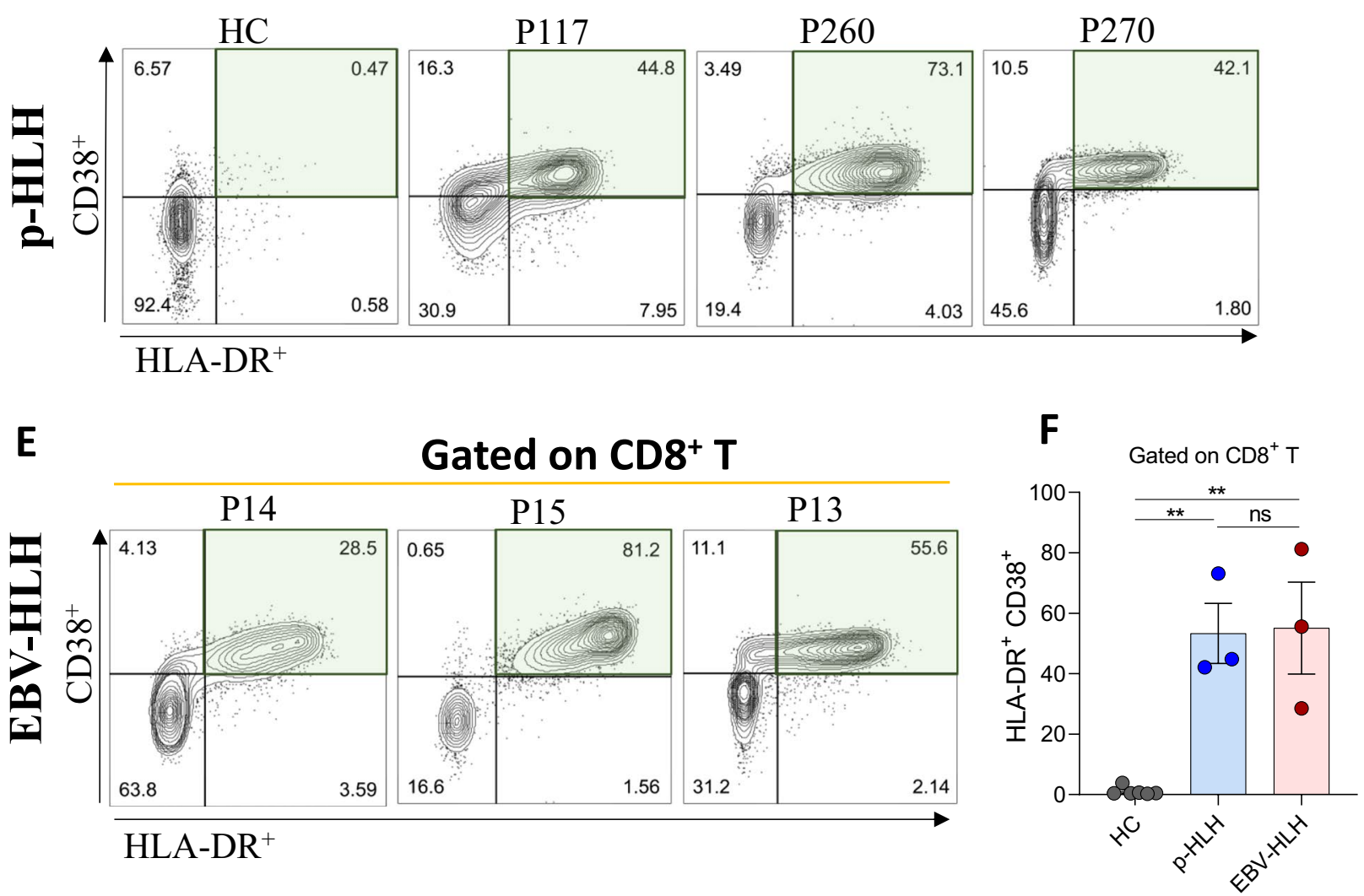
4Fig. 3 Flow cytometry analysis of $\mathrm{T}$ cell activation markers in three consecutive patients with T cell-EBV-HLH. A, B HLA$\mathrm{DR}^{+}$vs. $\mathrm{CD} 38^{+}$gated on effector memory (EM) $\mathrm{CD}^{+} \mathrm{T}$ cells in patients with p-HLH and T cell-EBV-HLH, respectively. C HLA$\mathrm{DR}^{+} \mathrm{CD} 38^{+} \mathrm{EM} \mathrm{CD} 8^{+} \mathrm{T}$ cells are significantly increased in patients with p-HLH and T cell-EBV-HLH, as compared to healthy controls $(* * * * p=<0.0001)$. However, comparable activation markers can be seen between p-HLH and T cell-EBV-HLH. D-F Similar results are noted when gating $\mathrm{HLA}-\mathrm{DR}^{+}$vs. $\mathrm{CD} 38^{+}$on $\mathrm{CD}^{+} \mathrm{T}$ cells $(* * p=<0.01)$

be indicated. Further prospective studies to enhance our understanding of immunobiology, genetic basis, and risk stratification-based therapies for patients with $\mathrm{T}$ cellEBV-HLH patients are needed to validate our results and improve outcome for this potentially fatal disorder.
Acknowledgements The authors wish to acknowledge Drs. Suhag Parikh and Sampath Prahalad for their critical review of the manuscript and feedback.

Author Contribution O.S. was involved in the collection of the data, data analysis, and manuscript writing. D.K., J.S., and A.M. were involved in the collection of the data and analysis. M.B., M.Q., S.Cho., L.L., H.E., M.H.W., and S.P. were involved in the clinical care and manuscript writing. S.C. was responsible for the project concept, design, analysis, manuscript writing, and project oversight.

Funding Oded Shamriz's position was supported by the Raymond F. Schinazi International Exchange Program (SIEP), Emory University School of Medicine, Atlanta, GA 30322, USA. This work was supported by NHLBI 1K08HL141635-01A1, Atlanta Pediatric Scholars Program K12 Scholar supported by grants K12HD072245 and U54AI082973 (to S.C.). The Mills Foundation (to S.C) and the Henagan Foundation ( to S.C).

\section{Gated on $\mathrm{EM} \mathrm{CD}^{+} \mathrm{T}$}

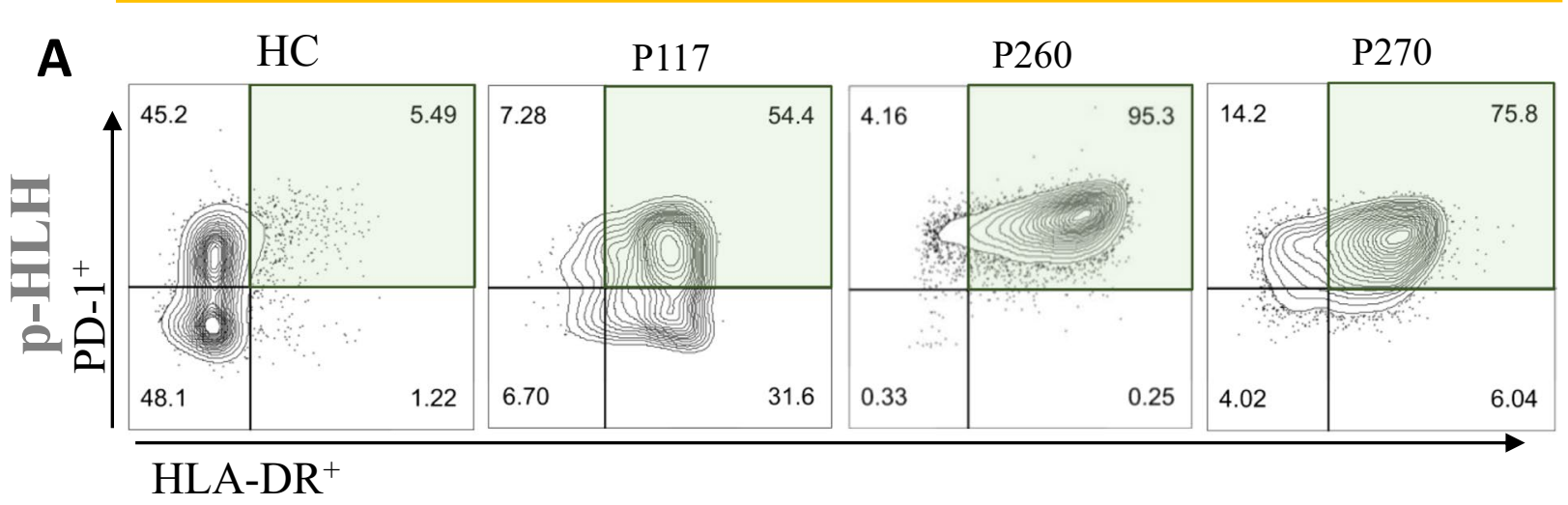

Gated on $\mathrm{EM} \mathrm{CD} 8^{+} \mathrm{T}$
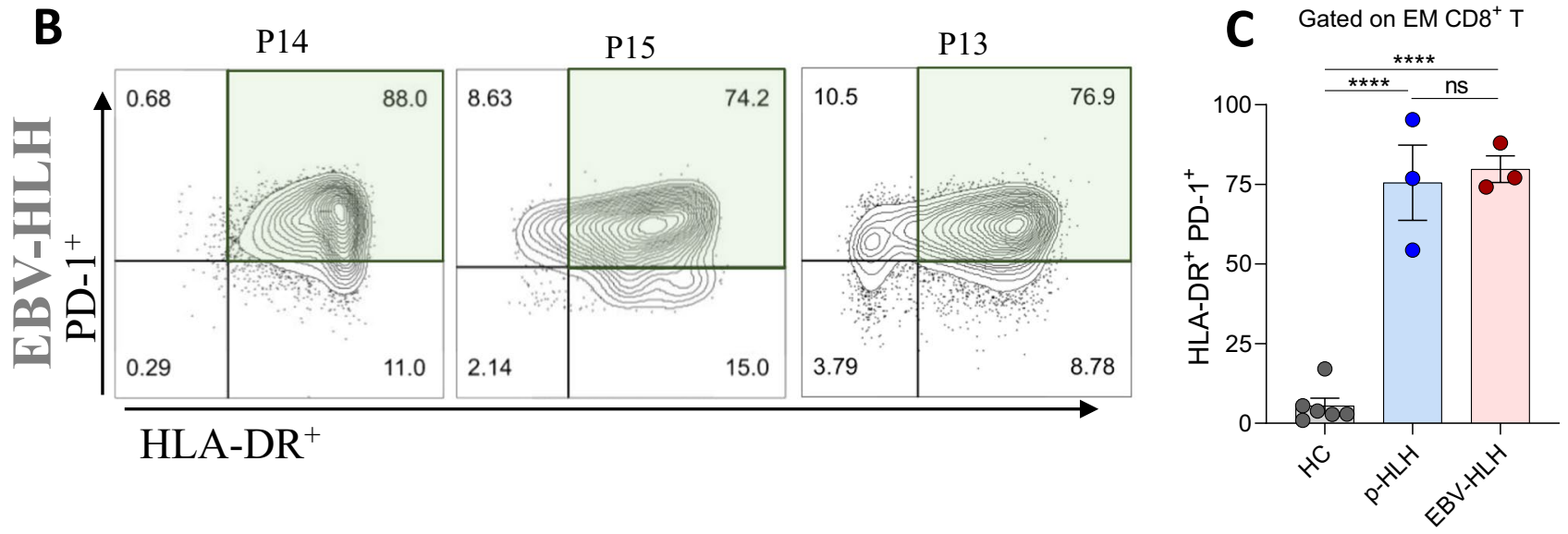

Fig. 4 Flow cytometry analysis of $\mathrm{T}$ cell activation markers in three consecutive patients with T cell-EBV-HLH. A, B HLA-DR ${ }^{+}$vs. $\mathrm{PD}-1^{+}$gated on EM CD8 ${ }^{+} \mathrm{T}$ cells in patients with p-HLH and T cell-
EBV-HLH, respectively. C HLA-DR ${ }^{+} \mathrm{PD}-1^{+}$EM CD8 ${ }^{+} \mathrm{T}$ cells are significantly increased in p-HLH and T cell-EBV-HLH, as compared to healthy controls $(* * * * p<0.0001)$ 
Table 5 Treatment outcome of T cell-EBV-HLH

\begin{tabular}{|c|c|c|c|c|c|c|}
\hline $\begin{array}{l}\text { Patient } \\
\text { number }\end{array}$ & $\begin{array}{l}\text { Critical care } \\
\text { required }\end{array}$ & Medical treatment & $\begin{array}{l}\text { HSCT con- } \\
\text { sidered }\end{array}$ & Response to therapy & $\begin{array}{l}\text { Current age } \\
\text { (years) }\end{array}$ & Outcome \\
\hline 1 & No & CSA, Dex, VP-16, Ritux & No & CR & 16.0 & Alive \\
\hline 2 & Yes & Dex, VP-16, Ritux & Yes & Refractory disease & - & Deceased \\
\hline 3 & Yes & CSA, Dex, VP-16, Ritux & Yes & CR & 12.4 & Alive \\
\hline 4 & Yes & Dex, VP-16 & Yes & Refractory disease & - & Deceased \\
\hline 5 & No & Dex, Ritux & No & $\mathrm{CR}$ & 7.2 & Alive \\
\hline 6 & Yes & $\begin{array}{l}\text { Dex, VP-16, Ritux, alemtuzumab, anakinra, } \\
\text { EPOCH chemo }\end{array}$ & Yes & Refractory disease & - & Deceased* \\
\hline 7 & Yes & CSA, Dex, VP-16, Ritux & No & $\mathrm{CR}$ & 15.4 & Alive \\
\hline 8 & Yes & Dex, VP-16, Ritux, alemtuzumab & Yes & In remission post-HSCT & 23.0 & Alive \\
\hline 9 & Yes & Dex, VP-16, Ritux, alemtuzumab & Yes & Relapsed post-HSCT & - & Deceased* \\
\hline 10 & No & Dex & No & $\mathrm{CR}$ & 4.4 & Alive \\
\hline 11 & No & Dex, VP-16, Ritux & Yes & $\mathrm{CR}$ & 3.5 & Alive \\
\hline 12 & No & Dex & No & $\mathrm{CR}$ & 6.2 & Alive \\
\hline 13 & No & Dex, Ritux & No & $\mathrm{CR}$ & 20.0 & Alive \\
\hline 14 & Yes & Dex, VP-16, Ritux, CHOP chemo, Nivo, Emap & Yes & $\begin{array}{l}\text { Refractory disease compli- } \\
\text { cated by COVID-19 }\end{array}$ & - & Deceased \\
\hline 15 & Yes & Dex, VP-16, Ritux, CHOP chemo, Nivo, Emap & Yes & Post-HSCT & 1.0 & Alive \\
\hline
\end{tabular}

CSA cyclosporine; Dex dexamethasone; Ritux rituximab; CR complete response; Nivo nivolumab; Emap emapalumab; HSCT hematopoietic stem cell transplantation; $C H O P$ cyclophosphamide, doxorubicin, vincristine, and prednisone; $E P O C H$ etoposide, vincristine, doxorubicin, cyclophosphamide, and prednisone

*Post-alemtuzumab had worsening in EBV viremia with an increase in ferritin

Data Availability Not applicable.

Code Availability Not applicable.

\section{Declarations}

Ethics Approval and Consent to Participate The study was approved by an institutional review board. Consent to participate was obtained from patients, who had further immune evaluation done.

Consent for Publication Not applicable.

Conflict of Interest S.C. serves on the advisory committee of SOBI. The other authors declare no competing interests.

\section{References}

1. Canna SW, Marsh RA. Pediatric hemophagocytic lymphohistiocytosis. Blood. 2020;135(16):1332-43. https://doi.org/10.1182/ blood.2019000936.

2. Jordan MB, Allen CE, Weitzman S, Filipovich AH, McClain KL. How I treat hemophagocytic lymphohistiocytosis. Blood. 2011;118(15):4041-52. https://doi.org/10.1182/ blood-2011-03-278127.

3. Janka GE, Lehmberg K. Hemophagocytic lymphohistiocytosis: pathogenesis and treatment. Hematology Am Soc Hematol Educ Program. 2013;2013:605-11. https://doi.org/10.1182/asheducati on-2013.1.605.

4. Chandrakasan S, Filipovich AH. Hemophagocytic lymphohistiocytosis: advances in pathophysiology, diagnosis, and treatment.
J Pediatr. 2013;163(5):1253-9. https://doi.org/10.1016/j.jpeds. 2013.06.053.

5. Jordan MB, Allen CE, Greenberg J, Henry M, Hermiston ML, Kumar A, et al. Challenges in the diagnosis of hemophagocytic lymphohistiocytosis: recommendations from the North American Consortium for Histiocytosis (NACHO). Pediatr Blood Cancer. 2019;66(11):e27929. https://doi.org/10.1002/pbc.27929.

6. Malinowska I, Machaczka M, Popko K, Siwicka A, Salamonowicz M, Nasilowska-Adamska B. Hemophagocytic syndrome in children and adults. Arch Immunol Ther Exp (Warsz). 2014;62(5):385-94. https://doi.org/10.1007/s00005-014-0274-1.

7. Chellapandian D, Das R, Zelley K, Wiener SJ, Zhao H, Teachey DT, et al. Treatment of Epstein Barr virus-induced haemophagocytic lymphohistiocytosis with rituximab-containing chemoimmunotherapeutic regimens. Br J Haematol. 2013;162(3):37682. https://doi.org/10.1111/bjh.12386.

8. Ishimura M, Eguchi K, Shiraishi A, Sonoda M, Azuma Y, Yamamoto H, et al. Systemic Epstein-Barr virus-positive T/NK lymphoproliferative diseases with SH2D1A/XIAP hypomorphic gene variants. Front Pediatr. 2019;7:183. https://doi.org/10.3389/fped. 2019.00183.

9. Toga A, Wada T, Sakakibara Y, Mase S, Araki R, Tone Y, et al. Clinical significance of cloned expansion and CD5 down-regulation in Epstein-Barr virus (EBV)-infected CD8+ T lymphocytes in EBV-associated hemophagocytic lymphohistiocytosis. J Infect Dis. 2010;201(12):1923-32. https://doi.org/10.1086/652752.

10. Ai J, Xie Z. Epstein-Barr virus-positive T/NK-cell lymphoproliferative diseases in Chinese mainland. Front Pediatr. 2018;6:289. https://doi.org/10.3389/fped.2018.00289.

11. Lin MT, Chang HM, Huang CJ, Chen WL, Lin CY, Chuang SS. Massive expansion of EBV+ monoclonal $\mathrm{T}$ cells with CD5 down regulation in EBV-associated haemophagocytic 
lymphohistiocytosis. J Clin Pathol. 2007;60(1):101-3. https:// doi.org/10.1136/jcp.2005.034371.

12. Jin Z, Wang Y, Wang J, Wu L, Pei R, Lai W, et al. Multivariate analysis of prognosis for patients with natural killer/T cell lymphoma-associated hemophagocytic lymphohistiocytosis. Hematology. 2018;23(4):228-34. https://doi.org/10.1080/10245332.2017. 1385191.

13. Cho EY, Kim KH, Kim WS, Yoo KH, Koo HH, Ko YH. The spectrum of Epstein-Barr virus-associated lymphoproliferative disease in Korea: incidence of disease entities by age groups. J Korean Med Sci. 2008;23(2):185-92. https://doi.org/10.3346/jkms.2008. 23.2.185.

14. Sawada A, Inoue M. Hematopoietic stem cell transplantation for the treatment of Epstein-Barr virus-associated T- or NK-cell lymphoproliferative diseases and associated disorders. Front Pediatr. 2018;6:334. https://doi.org/10.3389/fped.2018.00334.

15. Beutel K, Gross-Wieltsch U, Wiesel T, Stadt UZ, Janka G, Wagner HJ. Infection of T lymphocytes in Epstein-Barr virus-associated hemophagocytic lymphohistiocytosis in children of non-Asian origin. Pediatr Blood Cancer. 2009;53(2):184-90. https://doi.org/10. $1002 / p b c .22037$.

16. Henter JI, Horne A, Arico M, Egeler RM, Filipovich AH, Imashuku S, et al. HLH-2004: diagnostic and therapeutic guidelines for hemophagocytic lymphohistiocytosis. Pediatr Blood Cancer. 2007;48(2):124-31. https://doi.org/10.1002/pbc.21039.

17. Kimura H, Morishima T, Kanegane H, Ohga S, Hoshino Y, Maeda A, et al. Prognostic factors for chronic active EpsteinBarr virus infection. J Infect Dis. 2003;187(4):527-33. https:// doi.org/10.1086/367988.

18. Arai A. Advances in the study of chronic active Epstein-Barr virus infection: clinical features under the 2016 WHO classification and mechanisms of development. Front Pediatr. 2019;7:14. https://doi.org/10.3389/fped.2019.00014.

19. Cohen JI, Jaffe ES, Dale JK, Pittaluga S, Heslop HE, Rooney $\mathrm{CM}$, et al. Characterization and treatment of chronic active Epstein-Barr virus disease: a 28-year experience in the United States. Blood. 2011;117(22):5835-49. https://doi.org/10.1182/ blood-2010-11-316745.

20. Cohen JI, Kimura H, Nakamura S, Ko YH, Jaffe ES. EpsteinBarr virus-associated lymphoproliferative disease in nonimmunocompromised hosts: a status report and summary of an international meeting, 8-9 September 2008. Ann Oncol. 2009;20(9):1472-82. https://doi.org/10.1093/annonc/mdp064.

21. Bollard CM, Cohen JI. How I treat T-cell chronic active EpsteinBarr virus disease. Blood. 2018;131(26):2899-905. https://doi. org/10.1182/blood-2018-03-785931.

22. Cohen JI, Manoli I, Dowdell K, Krogmann TA, Tamura D, Radecki P, et al. Hydroa vacciniforme-like lymphoproliferative disorder: an EBV disease with a low risk of systemic illness in whites. Blood. 2019;133(26):2753-64. https://doi.org/10.1182/ blood.2018893750.

23. Latour S, Winter S. Inherited immunodeficiencies with high predisposition to Epstein-Barr virus-driven lymphoproliferative diseases. Front Immunol. 2018;9:1103. https://doi.org/10.3389/ fimmu.2018.01103.
24. Tangye SG, Palendira U, Edwards ES. Human immunity against EBV-lessons from the clinic. J Exp Med. 2017;214(2):269-83. https://doi.org/10.1084/jem.20161846.

25. Cohen JI. Primary immunodeficiencies associated with EBV disease. Curr Top Microbiol Immunol. 2015;390(Pt 1):241-65. https://doi.org/10.1007/978-3-319-22822-8_10.

26. Li FY, Chaigne-Delalande B, Kanellopoulou C, Davis JC, Matthews HF, Douek DC, et al. Second messenger role for $\mathrm{Mg}^{2+}$ revealed by human T-cell immunodeficiency. Nature. 2011;475(7357):471-6. https://doi.org/10.1038/nature10246.

27. Cohen JI, Niemela JE, Stoddard JL, Pittaluga S, Heslop H, Jaffe ES, et al. Late-onset severe chronic active EBV in a patient for five years with mutations in STXBP2 (MUNC18-2) and PRF1 (perforin 1). J Clin Immunol. 2015;35(5):445-8. https://doi.org/ 10.1007/s10875-015-0168-y.

28. Liu P, Pan X, Chen C, Niu T, Shuai X, Wang J, et al. Nivolumab treatment of relapsed/refractory Epstein-Barr virus-associated hemophagocytic lymphohistiocytosis in adults. Blood. 2020;135(11):826-33. https://doi.org/10.1182/blood.2019003886.

29. Chaturvedi V, Marsh RA, Lorenz AZ, Owsley E, Nguyen T, Goldman J, et al. T cell activation profiles distinguish hemophagocytic lymphohistiocytosis and early sepsis. Blood. 2020. https://doi.org/ 10.1182/blood.2020009499.

30. Kawabe S, Ito Y, Gotoh K, Kojima S, Matsumoto K, Kinoshita T, et al. Application of flow cytometric in situ hybridization assay to Epstein-Barr virus-associated T/natural killer cell lymphoproliferative diseases. Cancer Sci. 2012;103(8):1481-8. https://doi. org/10.1111/j.1349-7006.2012.02305.x.

31. Jha B, Mohan N, Gajendra S, Sachdev R, Goel S, Sahni T, et al. Prompt diagnosis and management of Epstein-Barr virus-associated post-transplant lymphoproliferative disorder and hemophagocytosis: a dreaded complication in a post-liver transplant child. Pediatr Transplant. 2015;19(7):E177-80. https://doi.org/10.1111/ petr. 12558 .

32. Makatsori M, Kiani-Alikhan S, Manson AL, Verma N, Leandro M, Gurugama NP, et al. Hypogammaglobulinaemia after rituximab treatment-incidence and outcomes. QJM. 2014;107(10):8218. https://doi.org/10.1093/qjmed/hcu094.

33. Marsh RA, Allen CE, McClain KL, Weinstein JL, Kanter J, Skiles J, et al. Salvage therapy of refractory hemophagocytic lymphohistiocytosis with alemtuzumab. Pediatr Blood Cancer. 2013;60(1):101-9. https://doi.org/10.1002/pbc.24188.

34. Kasahara Y, Yachie A, Takei K, Kanegane C, Okada K, Ohta $\mathrm{K}$, et al. Differential cellular targets of Epstein-Barr virus (EBV) infection between acute EBV-associated hemophagocytic lymphohistiocytosis and chronic active EBV infection. Blood. 2001;98(6):1882-8. https://doi.org/10.1182/blood.v98.6.1882.

35. Ishii E. Hemophagocytic lymphohistiocytosis in children: pathogenesis and treatment. Front Pediatr. 2016;4:47. https://doi.org/ 10.3389/fped.2016.00047.

Publisher's note Springer Nature remains neutral with regard to jurisdictional claims in published maps and institutional affiliations. 